\title{
Geospatial panorama of long-term care facilities in Brazil: a portrait of territorial inequalities
}

\section{Panorama geoespacial das Instituições de Longa Permanência para Idosos no Brasil: um retrato das desigualdades territoriais}

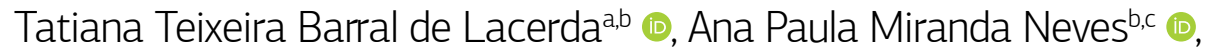 \\ Giselle Layse Andrade Buarque ${ }^{\mathrm{b}}$, Denise Cuoghi de Carvalho Veríssimo Freitas ${ }^{\mathrm{b}, \mathrm{d}} \bullet$ ,

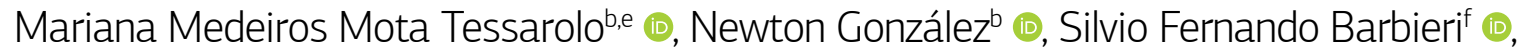

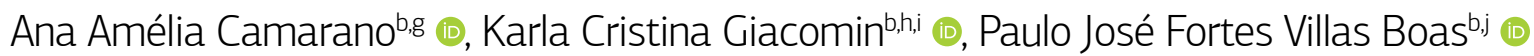

OBJECTIVES: To map the number and geospatial distribution of Brazilian long-term care facilities (LTCFs) for older adults. Additionally, we sought to highlight the relationship between these findings and the number of older people in the country's 27 Federation Units, demonstrating the growth of these facilities in the last decade. METHODS: This is a descriptive observational study, using secondary data, which was performed in 3 stages: 1) searching and consolidating national and subnational data from different sources and mapping LTCFs; 2) preparing a geospatial map using Brazilian postal codes; and 3) triangulating the number of facilities and of older people in each state and all 5 Brazilian regions. RESULTS: We found 7029 LTCFs in the country, mostly in the Southeast and South regions: São Paulo, Minas Gerais and Rio Grande do Sul had the highest numbers of facilities while states in the North region represented only 1.12\% of Brazilian LTCFs. Geospatial mapping highlighted that $64 \%$ of the 5570 Brazilian municipalities did not have any LTCFs for older adults. CONCLUSIONS: We observed a large difference between Brazilian regions regarding the provision of long-term care.

KEYWORDS: homes for the aged; demography, aged.

OBJETIVOS: Mapeamento do número e distribuição geoespacial das Instituições de Longa Permanência para idosos (ILPI) brasileiras. Além disso, procuramos destacar a relação entre estes resultados e o número de pessoas idosas nas 27 unidades de da federação, exibindo o crescimento dessas instalações na última década. METODOLOGıA: Estudo observacional descritivo, a partir de dados secundários, realizado em 3 etapas: 1) pesquisa e consolidação de dados nacionais e subnacionais de diferentes fontes e mapeamento de ILPI; 2) elaboração de mapa geoespacial utilizando o código de endereço postal do Brasil, e 3) triangulação do número de instituições com dados sobre o número dos idosos em cada estado e nas cinco regiões brasileiras. RESULTADOS: Encontramos 7.029 ILPI no país, principalmente nas regiões Sudeste e Sul: São Paulo, Minas Gerais e Rio Grande do Sul tiveram o maior número de instalações, enquanto os estados da região Norte representavam apenas 1,12\% das ILPI brasileiras. O mapeamento geoespacial destacou que 64\% dos 5570 municípios brasileiros não possuem ILPI para os idosos. CONCLUSÕES: Observamos uma grande diferença no Brasil em relação à prestação de cuidados de longa duração. PALAVRAS-CHAVE: instituição de longa permanência para idosos; demografia; idoso.

\footnotetext{
aDepartment of Physical Therapy, Pontifícia Universidade Católica de Minas Gerais - Belo Horizonte (MG), Brazil.

${ }^{b}$ National Front to Strengthen Long-Term Care Facilities for Older Adults - Belo Horizonte (MG), Brazil.

'Gero360 Soluções em Tecnologia Ltda, Rio de Janeiro (RJ), Brazil.

dPhysical Therapy Undergraduate, Faculdade Anhanguera, Ouro Verde Campus, Campinas (SP), Brazil.

eCasa de Repouso Aconchego Aracruz Ltda - Aracruz (ES), Brazil.

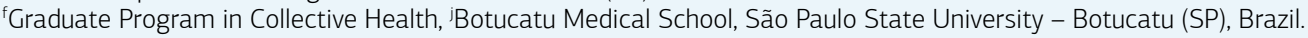

sDirectorate of Social Studies and Policies, Institute of Applied Economic Research - Brasília (DF), Brazil.

hBelo Horizonte Municipal Health Department - Belo Horizonte (MG), Brazil.

'Center for Studies in Public Health and Aging, Fundação Oswaldo Cruz - Belo Horizonte (MG), Brazil.

'Botucatu Medical School, São Paulo State University - Botucatu (SP), Brazil.

Correspondence data

Paulo José Fortes Villas Boas - Rua General Telles, 1.519 - CEP 18602-120 - Botucatu (SP), Brazil. E-mail: paulo.boas@unesp.br

Received on: 09/27/2021. Accepted on: 10/25/2021
}

How to cite this article: Lacerda TTB, Neves APM, Buarque GLA, Freitas DCCV, Tessarolo MMM, González N, Barbieri SF, Camarano AA, Giacomin KC, Villas Boas PJF. Geospatial panorama of long-term care facilities in Brazil: a portrait of territorial inequalities. Geriatr Gerontol Aging. 2021;15:e0210060. https://doi.org/10.53886/gga.e0210060

https://doi.org/10.53886/gga.e0210060 


\section{INTRODUCTION}

With the acceleration of population aging, the rate of non-communicable chronic diseases has increased the chances of functional disability in older adults, enhancing the complexity of care. Historically, particularly in low- and middle-income countries (LMIC), care for older adults with functional decline has taken place inside the home, primarily by female caregivers. Factors such as the migration of younger people to urban areas in search of employment, the progressive employability of women, and the continuous decline in fertility lead to smaller families and a higher proportion of older adults living alone. As the long-term care sector is relatively immature and incipient in most LMICs, this higher proportion of older adults dependent on care increases the need to consider other ways to make care available and affordable.

Long-term care facilities (LTCFs) are one of the longterm care options available for older citizens with functional dependence. They provide 24-hour care as an alternative for older adults with complex physical or cognitive disabilities, offering support for people with cognitive, health, and care needs and to their families. ${ }^{1-3}$

In Latin America and other LMICs, LTCFs have historically been created to house vulnerable people. Recently, these facilities acquired new characteristics and started to offer hybrid services, adding psychological and health care to social assistance actions. In addition to being a place of collective residence, LTCFs provide rehabilitation services for older adults with functional decline who require support for performing activities of daily living.

Due to characteristics related to welfare policies, non-profit facilities (known as philanthropic homes) predominated in Brazil in a fairly recent past. However, recent evidence showed a considerable growth in the number of for-profit facilities in the last few years. ${ }^{1}$ The increased complexity of care due to a higher proportion of dependent older adults without other longterm care options has possibly influenced this growth. Brazilian public policies for long-term care, however, are insufficient, and the sector faces social prejudice and a certain invisibility.

The coronavirus disease 2019 (COVID-19) pandemic disproportionately burdened the older population living in LTCFs ${ }^{4-7}$ On the other hand, it highlighted the need to give visibility and support to LTCFs, broadening the focus of public policies, health care, and research. ${ }^{2}$ For these measures to be successful, the first step must be to identify the sector's characteristics.

Considering the scenario of emergency issues related to coping with COVID-19 in Brazilian LTCFs, the National Front to Strengthen LTCFs for Older Adults (Frente Nacional de Fortalecimento à ILPI [FN-ILPI]) was created in April 2020.
It aimed to stimulate actions to support the sector and undertake proposals to improve public policies for long-term care.

Due to the unavailability of a single source aggregating national data, in this study researchers from the FN-ILPI aimed to present the geospatial distribution of Brazilian LTCFs, the relationship between the number of these facilities and that of older adults living in each of the 27 Brazilian states, and their numerical evolution in the last decade.

\section{METHODS}

This is a descriptive observational study performed through the survey of secondary data. The study consisted of 3 stages:

Step 1: As no single database brings together information on Brazilian LTCFs at national and regional levels, the researchers gathered and compiled data from multiple sources. Between September 2020 and August 2021, we collected data from the 2019 census of the Unified Social Assistance System (Sistema Unificado de Assistência Social); municipal and state social assistance and health secretariats; councils on the rights of older persons; state public prosecutors' offices; and municipal and state health surveillance entities. ${ }^{8}$ A preliminary register was prepared, consolidating data from these different sources and excluding duplicate records and facilities that did not care for older adults. Data were grouped by region and by state, with the number and percentage of LTCFs.

Step 2: After standardizing the location of LTCFs with postal codes by using the Brazilian Postal Service website (https://buscacepinter.correios.com.br/app/faixa_cep_uf_localidade/index.php), we added a 7-digit code for each municipality according to the Brazilian Institute of Geography and Statistics (Instituto Brasileiro de Geografia e Estatística [IBGE]) (http://blog.mds.gov.br/redesuas/lista-de-municipios-brasileiros) by adopting the Postgresql open-source, object-relational database (https://www.postgresql.org/). We consolidated data by IBGE code and municipality. Then, we generated a comma-delimited CSV file to be used in QGIS, a free and open Geographic Information System (https://qgis.org/pt_BR/site/). For mapping geospatial distribution, we downloaded and added the vector layer of Brazilian municipalities from the IBGE website (https://www.ibge. gov.br/geociencias/organizacao-doterritorio/malhas-territoriais/15774-malhas.html?=\&t=downloads).

Step 3: After obtaining the geospatial distribution of the facilities, it was critical to analyze whether the number of LCTFs was suitable for addressing the needs of the Brazilian older population. First, we analyzed the growth of LCTFs between 2010 and 2021, comparing the number of LCTFs mapped in this research with 2010 data from the Institute of Applied 
Economic Research (Instituto de Pesquisa Econômica Aplicada [IPEA] $).{ }^{9-13}$ Considering population projections by IBGE,${ }^{14}$ we established the proportion of LTCFs and their residents within 2 groups (Brazilians over 60 years old and over 75 years old). The first group represents the Brazilian older population in general. The second one represents those with potential demand for long-term care due to functional limitations, assuming that this proportion is only an estimate and may not describe the actual situation of care dependence in this population. ${ }^{15}$

\section{Ethical and legal aspects}

Ethical approval was waived for this research as it dealt with publicly accessible secondary data.

\section{RESULTS}

During the first step, we identified 7029 LTCFs. Table $1^{14}$ shows their distribution by region and state and the population aged over 60 and 75 years, respectively. The states with

Table 1. Distribution of long-term care institutions for older adults by region and state, residents aged over 60 and over 75 years and ratio between them, and number of long-term care facilities.

\begin{tabular}{|c|c|c|c|c|c|c|c|c|}
\hline \multirow{2}{*}{$\begin{array}{l}\text { Region/Federation } \\
\text { Unit }\end{array}$} & \multicolumn{2}{|c|}{ LTCFs } & \multicolumn{2}{|c|}{ Population > $60 \mathrm{y}^{*}$} & \multirow{2}{*}{$\begin{array}{c}\text { Population }>60 \mathrm{yl} \\
\text { number LTCFs }\end{array}$} & \multicolumn{2}{|c|}{ Population > $75 \mathrm{y}^{*}$} & \multirow{2}{*}{$\begin{array}{c}\text { Population }>75 \mathrm{yl} \\
\text { number LTCFs }\end{array}$} \\
\hline & $n$ & $\%$ & $n(x$ 1000) & $\%$ & & $n(x$ 1000) & $\%$ & \\
\hline Southeast & 4232 & 60.21 & 15094 & 45.94 & 3567 & 3,996 & 45.76 & 944 \\
\hline São Paulo & 2412 & 34.31 & 7413 & 22.56 & 3073 & 1924 & 22.03 & 798 \\
\hline Minas Gerais & 1116 & 15.88 & 3540 & 10.77 & 3172 & 971 & 11.12 & 870 \\
\hline Rio de Janeiro & 612 & 8.71 & 3519 & 10.71 & 5750 & 936 & 10.72 & 1529 \\
\hline Espírito Santo & 92 & 1.31 & 622 & 1.89 & 6761 & 165 & 1.89 & 1793 \\
\hline South & 1874 & 26.66 & 5201 & 15.83 & 2775 & 1340 & 1.35 & 715 \\
\hline Rio Grande do Sul & 1098 & 15.62 & 2250 & 6.85 & 2049 & 619 & 7.09 & 564 \\
\hline Paraná & 530 & 7.54 & 1821 & 5.54 & 3436 & 450 & 5.15 & 849 \\
\hline Santa Catarina & 246 & 3.50 & 1130 & 3.44 & 4593 & 271 & 3.10 & 1102 \\
\hline Northeast & 493 & 7.01 & 8445 & 25.70 & 17130 & 2401 & 27.50 & 4870 \\
\hline Bahia & 182 & 2.59 & 2262 & 6.89 & 12429 & 665 & 7.62 & 3654 \\
\hline Pernambuco & 94 & 1.34 & 1515 & 4.61 & 16117 & 384 & 4.40 & 4085 \\
\hline Paraíba & 53 & 0.75 & 591 & 1.80 & 11151 & 176 & 2.02 & 3321 \\
\hline Ceará & 41 & 0.58 & 1390 & 4.23 & 33902 & 429 & 4.91 & 10463 \\
\hline Maranhão & 34 & 0.48 & 880 & 2.68 & 25882 & 247 & 2.83 & 7265 \\
\hline Rio Grande do Norte & 33 & 0.47 & 522 & 1.59 & 15818 & 160 & 1.83 & 4848 \\
\hline Alagoas & 25 & 0.36 & 490 & 1.49 & 19600 & 119 & 1.36 & 4760 \\
\hline Sergipe & 18 & 0.26 & 285 & 0.87 & 15833 & 76 & 0.87 & 4222 \\
\hline Piauí & 13 & 0.18 & 510 & 1.55 & 39231 & 145 & 1.66 & 11154 \\
\hline Central-West & 351 & 4.99 & 2155 & 6.56 & 6140 & 518 & 5.93 & 1476 \\
\hline Goiás & 215 & 3.06 & 988 & 3.01 & 4595 & 247 & 2.83 & 1149 \\
\hline Mato Grosso do Sul & 71 & 1.01 & 375 & 1.14 & 5282 & 91 & 1.04 & 1282 \\
\hline Mato Grosso & 49 & 0.70 & 397 & 1.21 & 8102 & 88 & 1.01 & 1796 \\
\hline Distrito Federal & 16 & 0.23 & 395 & 1.20 & 24688 & 92 & 1.05 & 5750 \\
\hline North & 79 & 1.12 & 1959 & 5.96 & 24797 & 477 & 5.46 & 6038 \\
\hline Pará & 25 & 0.36 & 966 & 2.94 & 38640 & 240 & 2.75 & 9600 \\
\hline Tocantins & 21 & 0.30 & 210 & 0.64 & 10000 & 56 & 0.64 & 2667 \\
\hline Rondônia & 15 & 0.21 & 213 & 0.65 & 14200 & 50 & 0.57 & 3333 \\
\hline Amazonas & 10 & 0.14 & 368 & 1.12 & 36800 & 80 & 0.92 & 8000 \\
\hline Acre & 5 & 0.07 & 88 & 0.27 & 17600 & 25 & 0.29 & 5000 \\
\hline Amapá & 2 & 0.03 & 72 & 0.22 & 36000 & 18 & 0.21 & 9000 \\
\hline Roraima & 1 & 0.01 & 42 & 0.13 & 42000 & 8 & 0.09 & 8000 \\
\hline Brazil & 7029 & 100 & 32854 & 100 & 4674 & 8732 & 100 & 1242 \\
\hline
\end{tabular}

*LTCF: long-term care facilities; y: years; *percentage of the population over 60 years old in relation to the Brazilian population over 60 years old..$^{14}$ 
the highest number of LTCFs were São Paulo (34.31\%), Minas Gerais (15.88\%), and Rio Grande do Sul (15.62\%), while states in the North region concentrated only $1.12 \%$ of the country's LTCFs. When we considered the supply of LTCFs and the potential population requiring long-term care (people aged 75 and over), the mean national ratio was 8732 people over 75 years of age per LTCF. When we analyzed this ratio in regional terms, the disparity worsened: in the South region, there were approximately 715 people over 75 years of age per LTCF; in the Northeast region, the ratio was 4870 ; and in the North region, it increased to 6 038, with emphasis on Amapá and Pará, where this number reached more than 9000 older people for each existing LTCF. It is interesting to note the ratio of 11,154 older people over 75 years of age per LTCF in the state of Piauí when compared to that found in Rio Grande do Sul (564), suggesting a potentially low availability of facilities in Piauí.

Based on the distribution of LTCFs by municipality, we identified the 5 municipalities with the highest number of LTCFs, namely: São Paulo, with 810 units (11.52\%); Porto Alegre, with 287 (4.08\%); Belo Horizonte, with 268 (3.81\%); Rio de Janeiro, with 223 (3.17\%); and Curitiba, with 130 $(1.84 \%)$. Figure 1 presents the geospatial distribution of LTCFs per municipality in Brazil.

Out of 5570 Brazilian municipalities, only $36.22 \%$ ( $n=2$ 018) had LTCFs. The states with the highest number of cities with at least one LTCF were Rio de Janeiro (71.74\%), Goiás (65.45\%), São Paulo (62.48\%), Mato Grosso do Sul (60.76\%), and Minas Gerais (56.15\%) (Table 2). In the state of Piauí, only $2.23 \%$ of all municipalities had at least one LTCF.

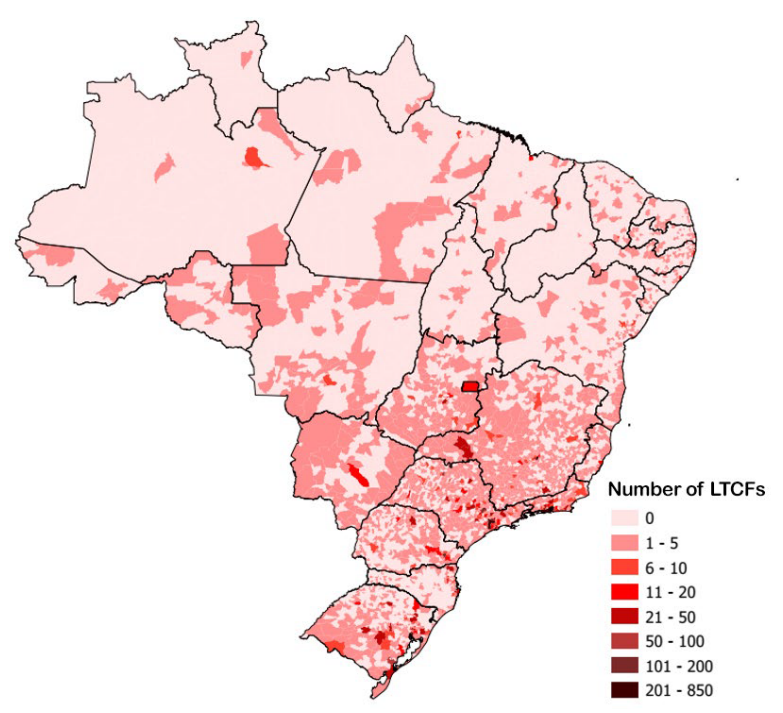

Figure 1. Mapping of the geospatial distribution of LTCFs in Brazil by municipality. LTCFs: long-term care facilities.
Table $3^{9-13}$ shows the evolution of the number of LTCFs between 2010 and 2021. Significant growth was observed in the states of Amazonas (233\%) and Rio Grande do Sul (217\%); on the other hand, we found a reduction of $50 \%$ in Roraima.

Table 2. Number of municipalities and percentage of municipalities with at least one long-term care facility.

\begin{tabular}{|c|c|c|c|}
\hline \multirow{2}{*}{$\begin{array}{l}\text { Region/Federation } \\
\text { Unit }\end{array}$} & \multirow{2}{*}{$\begin{array}{l}\text { Municipalities } \\
\text { (n) }\end{array}$} & \multicolumn{2}{|c|}{$\begin{array}{l}\text { Municipalities } \\
\text { with LTCFs }\end{array}$} \\
\hline & & $\mathbf{n}$ & $\%$ \\
\hline Southeast & 1668 & 984 & 58.99 \\
\hline Espírito Santo & 78 & 36 & 46.15 \\
\hline Minas Gerais & 853 & 479 & 56.15 \\
\hline Rio de Janeiro & 92 & 66 & 71.74 \\
\hline São Paulo & 645 & 403 & 62.48 \\
\hline South & 1191 & 479 & 40.22 \\
\hline Paraná & 399 & 224 & 56.14 \\
\hline Rio Grande do Sul & 487 & 182 & 37.37 \\
\hline Santa Catarina & 295 & 73 & 24.75 \\
\hline Northeast & 1793 & 250 & 13.94 \\
\hline Alagoas & 102 & 10 & 9.80 \\
\hline Bahia & 417 & 89 & 21.34 \\
\hline Ceará & 184 & 22 & 11.96 \\
\hline Maranhão & 217 & 15 & 6.91 \\
\hline Paraíba & 223 & 30 & 13.45 \\
\hline Pernambuco & 184 & 47 & 25.54 \\
\hline Piauí & 224 & 5 & 2.23 \\
\hline Rio Grande do Norte & 167 & 21 & 12.57 \\
\hline Sergipe & 75 & 11 & 14.67 \\
\hline Central-West & 499 & 252 & 50.50 \\
\hline Distrito Federal* & 33 & 3 & 9.09 \\
\hline Goiás & 246 & 161 & 65.45 \\
\hline Mato Grosso do Sul & 79 & 48 & 60.76 \\
\hline Mato Grosso & 141 & 40 & 28.37 \\
\hline North & 450 & 53 & 11.78 \\
\hline Acre & 22 & 4 & 18.18 \\
\hline Amazonas & 62 & 3 & 4.84 \\
\hline Amapá & 16 & 2 & 12.50 \\
\hline Pará & 144 & 18 & 12.50 \\
\hline Rondônia & 52 & 10 & 19.23 \\
\hline Roraima & 15 & 1 & 6.67 \\
\hline Tocantins & 139 & 15 & 10.79 \\
\hline Total/mean & 5601 & 2018 & 36.02 \\
\hline
\end{tabular}

LTCF: long-term care facilities; *Distrito Federal - 33 administrative regions, considered as a municipality for the purpose of this analysis. 
Table 3. Differences in the number of long-term care facilities between 2010 and 2021.

\begin{tabular}{|c|c|c|c|}
\hline \multirow{2}{*}{$\begin{array}{l}\text { Region/Federation } \\
\text { Unit }\end{array}$} & \multicolumn{3}{|c|}{ Number of LTCFs } \\
\hline & $\begin{array}{c}\text { IPEA } \\
2010^{*}\end{array}$ & $\begin{array}{c}\text { FN-ILPI } \\
2021^{\dagger}\end{array}$ & $\begin{array}{l}\text { Differences } \\
(\%)\end{array}$ \\
\hline Southeast & 2255 & 4232 & +88 \\
\hline São Paulo & 1219 & 2412 & +98 \\
\hline Minas Gerais & 694 & 1116 & +61 \\
\hline Rio de Janeiro & 290 & 612 & +111 \\
\hline Espírito Santo & 52 & 92 & +77 \\
\hline South & 693 & 1874 & +170 \\
\hline Rio Grande do Sul & 346 & 1098 & +217 \\
\hline Paraná & 251 & 530 & +111 \\
\hline Santa Catarina & 96 & 246 & +156 \\
\hline Central-West & 249 & 351 & +41 \\
\hline Goiás & 157 & 215 & +37 \\
\hline Mato Grosso do Sul & 49 & 71 & +45 \\
\hline Mato Grosso & 28 & 49 & +75 \\
\hline Distrito Federal & 15 & 16 & +7 \\
\hline Northeast & 302 & 493 & +63 \\
\hline Bahia & 82 & 182 & +122 \\
\hline Pernambuco & 93 & 94 & +1 \\
\hline Paraíba & 19 & 53 & +179 \\
\hline Ceará & 30 & 41 & +37 \\
\hline Maranhão & 12 & 34 & +183 \\
\hline Rio Grande do Norte & 29 & 33 & +14 \\
\hline Alagoas & 16 & 25 & +56 \\
\hline Sergipe & 15 & 18 & +20 \\
\hline Piauí & 6 & 13 & +117 \\
\hline North & 49 & 79 & +61 \\
\hline Pará & 16 & 25 & +56 \\
\hline Tocantins & 14 & 21 & +50 \\
\hline Rondônia & 7 & 15 & +114 \\
\hline Amazonas & 3 & 10 & +233 \\
\hline Acre & 5 & 5 & 0 \\
\hline Amapá & 2 & 2 & 0 \\
\hline Roraima & 2 & 1 & -50 \\
\hline Total & 3548 & 7029 & +146 \\
\hline
\end{tabular}

LTCF: long-term care facilities; *Institute of Applied Economic Research (IPEA) "Characteristics of Long-Term Care Facilities" survey ${ }^{9-13}$; 'Data from the National Front to Strengthen Long-Term Care Facilities for Older Adults (FN-ILPI).

\section{DISCUSSION}

The COVID-19 pandemic brought to light the lack of data on LTCFs in Brazil. At the national level, no database currently gathers minimal information on the number and characteristics of facilities and older residents, which is fundamental for dealing with sanitary and health emergencies. LTCFs are part of the Line of Care for Comprehensive Health Care of Older People, a document prepared by the Ministry of Health to guide states and municipalities in the construction and implementation of eldercare. ${ }^{16}$ The lack of data on this matter highlights the invisibility of these units and their residents. ${ }^{17}$

Despite Brazil's continental dimensions, its contributions to the literature on the long-term care sector were not ranked among the main 15 countries, where the United States, Canada, and England stood out. ${ }^{18}$ The few Brazilian studies found between 1999 and 2018 focused on resident outcomes and deficit-based approaches. Authors highlight that research related to the workforce and older person-centered care, as well as the improvement of quality of care, are emerging very slowly and seem to be poorly comprehensive and representative. ${ }^{19}$

The invisibility of Brazilian LTCFs can be evidenced by the lack of basic information on these facilities, for example: how many are they; where are they located; what is their legal nature; and what services and activities they offer to their residents. The last national survey was performed in 2007 and published in 2010 by IPEA, which assessed the characteristics of LTCFs in the 5 Brazilian regions. In this research, 3548 facilities were identified, most of them private and non-profit. Private for-profit facilities constituted approximately one-quarter of the total and only $6.61 \%$ of them were public or mixed. ${ }^{3}$

The rapid growth of the population with non-communicable chronic diseases and disabilities in activities of daily living will require support for long-term care. ${ }^{20,21} \mathrm{It}$ is of crucial importance to understand the health and social care needs of these people and to develop measures that establish effective and efficient care programs and structures. Unlike epidemiological studies that assess inpatient or primary care units, for long-term care there are no comparable data sources to inform regional or national policies, including those relating to LTCFs.

The available studies assess the functional and social consequences of health conditions of the population assisted by these facilities. In Brazil, according to Born and Boechat, ${ }^{22}$ even though LTCFs are part of the social assistance network, they are generally created due to the needs of the community, and not as a result of the implementation of a longterm care policy. ${ }^{22}$

A 2010 Brazilian study identified 3548 facilities distributed throughout the 5 Brazilian regions with 84000 older residents, who were predominantly female (57.35\%). At that time, around $20 \%$ of Brazilian municipalities had at least one 
LTCF. ${ }^{3}$ Compared to this survey, ${ }^{3}$ the results of our study show an increase of $55.62 \%$ in the number of municipalities with at least one LTCF. The states of São Paulo, Minas Gerais, Rio Grande do Sul, Rio de Janeiro, and Paraná (located in the Southeast and South regions) had the highest numbers of LTCF, while Roraima, Amapá, and Acre (in the North region) and Piauí and Rio Grande do Norte (in the Northeast region) had the smallest. This regional behavior also occurred when analyzing the ratio between the numbers of older people and of available LTCFs: this value is higher in the Northeast and North regions and lower in the South and Southeast regions. The states with the most municipalities with at least one LTCF were Rio de Janeiro, São Paulo, and Goiás, whereas the states of Amazonas and Roraima had the lowest numbers of municipalities with this kind of facility.

Despite the identification of more than 7000 facilities throughout the Brazilian territory, we observed an unequal distribution, whether in absolute or relative numbers, when analyzing the ratio between the number of people aged over 60 or 75 years and the number of LTCFs. A heterogeneous geographic distribution of these facilities has also been reported in other countries such as the United States, where the National Study of Long-Term Care Providers driven by the National Center for Health Statistics showed that 40.83\% of all LTCFs were located in the American West region. ${ }^{23}$ A study by Wang et al. also showed a large geographic disparity between nursing homes, and only around $4.44 \%$ of them were located in rural areas. ${ }^{24}$

Dintrans, ${ }^{25}$ in a study that aimed to identify the determinants of the geographic location of LTCFs in Chile, showed that facilities tend to be concentrated in urban and central areas with high demand, being more common in municipalities with older populations and higher income. According to the author ${ }^{24}$ the location of LTCFs is closely related to demand, including economic and demographic factors. Although our results do not allow us to identify these determinants, it is possible to infer that they also apply to the Brazilian scenario. The North and Northeast regions, with the lowest supply of LTCFs, are also known to have the most municipalities with low socioeconomic development and reduced health care services in relation to other regions. ${ }^{26}$

In the study by Camarano and Kanso, ${ }^{3}$ the number of institutionalized older people represented less than 1\% of the Brazilian population over 60 years old, with a mean of 30 residents per LTCF. In a survey conducted in Chile, the proportion of institutionalized older adults was also around $1 \%$, with a similar mean number of older people per LTCF (28.81). ${ }^{26}$ However, the Chilean study showed the existence of $164(47.5 \%)$ municipalities in the country without any
LTCF, while in Brazil this is the reality of 3583 (64.0\%) municipalities. These data reinforce the fact that Brazil has a gap in long-term care, even when considering Latin American countries.

According to data from a population-based study of community-dwelling older people, the Brazilian Longitudinal Study of Aging (Estudo Longitudinal de Saúde do Idoso [ELSI]), 23\% of Brazilian older people have care demands, but $24 \%$ of their family caregivers need to stop working or studying to provide care, given the patent insufficiency of long-term care policies. ${ }^{27}$ The existence of LTCFs in a person's city of residence is part of a long-term care policy, as its absence implies the need for institutionalization in facilities located far from their home; this can compromise the social and family bonds with difficulties in visitation, contributing to break ties with family and friends.

The long-term care sector, which includes LTCFs, is under constant pressure both from a financial point of view and due to the increase in the older population; this directly affects the performance of the entire health care and social assistance systems, compromising the implementation of policies designed to support older adults who require it. This aspect was more evident in Brazilian LTCFs with the COVID-19 pandemic. ${ }^{28}$ The 2015 International Labor Organization report indicated that Brazil, among 46 countries, had a 100\% deficit in the provision of long-term care. ${ }^{29}$ As age is independently associated with the chance residing in LTCFs, the number of older people living in these facilities is expected to continue increasing exponentially. ${ }^{30}$

Our results point to an absence of standardization and intersectoral cooperation in the way data on LTCF are collected, shared, and used. In addition, the offer of this service reflects the inequality and heterogeneity of aging, and almost two-thirds of Brazilian municipalities still do not have this kind of structure for supporting older people who demand longterm care that cannot be supplied by their families. This aspect is worrisome, particularly in a country of such large dimensions and experiencing rapid population aging such as Brazil.

All these results reinforce the need to build a long-term care policy that recognizes LTCFs as one of its elements and provides a national registry of facilities that is always up-to-date and accessible to public policy managers and the interested population. Access to data on LTCF location, the profile of the assisted population, care team, and service costs will enable effective monitoring and improvement of care.

Our work has some limitations. The first one concerns the number of mapped facilities, which was based on secondary sources. In the future, this research group will verify the information through field research. It is known that the opening 
and closing situation of these facilities is quite dynamic, especially given the financial and health challenges that the COVID-19 pandemic still produces. Another limitation is that the data obtained so far do not allow us to establish a relationship between the number of older people per existing vacancy, forms of financing, and the care team; this kind of information would allow a more thorough analysis of our reality. In addition, it is worth noting that data used to compare the evolution of the number of LTCF between 2010 and 2021 came from different sources and were collected using different methodologies, which requires careful comparisons.

\section{CONCLUSION}

We identified 7029 LTCFs in Brazil, with huge geographic variations in terms of regional distribution, the number of municipalities that have at least one facility, and the ratio between the number of people over 60 years old and especially over 75 years old and the number of LTCFs.

Given the current demographic and epidemiological scenario in Brazil, it is essential to recognize the special needs for health care and social assistance that population aging imposes in terms of continuing care demands. In this sense, this study highlighted the need for robust research to better understand the characteristics of Brazilian LTCFs, further investigating the profile of residents and staff working in these facilities and types of funding in order to improve management and quality of care. These measures may contribute for LTCFs and their residents to achieve the necessary visibility among public managers and civil society in order to allow and demand the immediate implementation of long-term care policies.

\section{ACKNOWLEDGMENTS}

Our special recognition and thanks to all the researchers and collaborators of the FN-LTCF research and to all municipal and state public agencies that contributed by sharing information.

\section{CONFLICTS OF INTEREST}

The authors declare no conflicts of interest.

\section{FUNDING}

This research did not receive any specific grant from funding agencies in the public, commercial, or not-forprofit sectors.

\section{AUTHORS' CONTRIBUTION}

TTBL: conceptualization, data curation, formal analysis, investigation, methodology, project administration, validation, writing - original draft, writing - review \& editing. APMN: conceptualization, data curation, formal analysis, investigation, methodology, validation, writing - original draft, writing review \& editing. GLAB: conceptualization, data curation, formal analysis, investigation, methodology, validation, writing - original draft, writing - review \& editing. DCCVF: conceptualization, data curation, formal analysis, investigation, methodology, validation, writing - review \& editing. MMMT: conceptualization, data curation, formal analysis, investigation, methodology, validation, writing - review \& editing. NG: conceptualization, data curation, formal analysis, investigation, methodology, validation, writing - review \& editing. SFB: data curation, formal analysis, validation, writing - review \& editing. AAC: writing - review \& editing. KCG: conceptualization, investigation, methodology, writing - review \& editing. PJFVB: conceptualization, data curation, formal analysis, investigation, methodology, project administration, validation, writing - original draft, writing - review \& editing.

\section{REFERENCES}

1. Gordon AL. Long-term care facilities and research: how COVID-19 changes things. Geriatr Gerontol Aging. 2020;14(4):225-7.

2. Neves APM. Envelhecimento, cuidados e design: explorando o campo de possibilidades das Instituições de Longa Permanência para Idosos [dissertação]. Rio de Janeiro: Pontifícia Universidade Católica do Rio de Janeiro; 2020.

3. Camarano AA, Kanso S. As instituições de longa permanência para idosos no Brasil. Rev Bras Est Pop. 2010;27(1):233-5. https://doi. org/10.1590/S0102-30982010000100014

4. Comas-Herrera A, Zalakaín J, Lemmon E, Henderson D, Litwin C, Hsu AT, et al. Mortality associated with COVID-19 outbreaks in care homes: early international evidence. LTC Responses to COVID-19. Available from: https://ltccovid.org/2020/04/12/mortality-associated-withcovid-19-outbreaks-in-care-homes-early-international-evidence/. Accessed in Aug 2, 2021.

5. D’Adamo H, Yoshikawa T, Ouslander JG. Coronavirus disease 2019 in geriatrics and long-term care: The ABCDs of COVID-19. J Am Geriatr Soc. 2020;68(5):912-7. https://doi.org/10.1111/jgs.16445.

6. Kemenesi G, Kornya L, Tóth GE, Kurucz K, Zeghbib S, Somogyi BA, et al Nursing homes and the elderly regarding the COVID-19 pandemic: situation report from Hungary. Geroscience. 2020;42(4):1-7. https:// doi:10.1007/s11357-020-00195-z. 
7. Villas Boas PJF, Bremenkamp MG, Roriz Filho JS, Kairalla MC, Gomes DCA, Mello RGB, et al. Recommendations for the prevention and control of coronavirus infections (SARS-CoV-2) in long term care facilities. Geriatr Gerontol Aging. 2020;14(2):134-7. https://doi. org:10.5327/Z2447-2123202020142ESP3.

8. Domingues MARC, Wachholz PA, Silva CB, Peres LCS, Chacon PF, Bezerra PCL, et al. Methodological description of mapping Brazilian long-term care facilities for older adults. Preprint. 2021. https://doi. org/10.1590/SciELOPreprints.3035.

9. Camarano AA. Camarano AA. Características das instituições de longa permanência para idosos - região Centro-Oeste. Available from: https://www.ipea.gov.br/portal/images/stories/PDFs/livros/ Livro_CaractdasInstituicoesRegiao_CentroOeste.pdf. Accessed in Nov 10, 2021.

10. Camarano AA. Características das instituições de longa permanência para idosos - região Nordeste. Available from: https://www.ipea.gov.br/ portal/images/stories/PDFs/livros/Livro__CaractdasInstituicoesRegiao_ Nordeste.pdf. Accessed in Nov 10, 2021.

11. Camarano AA. Características das instituições de longa permanência para idosos - região Norte. Available from: https:// www.ipea.gov.br/portal/images/stories/PDFs/livros/Livro CaractdasInstituicoesRegiao_Norte.pdf. Accessed in Nov 10, 2021.

12. Camarano AA. Características das instituições de longa permanência para idosos - região Sudeste. Available from: https://www.ipea.gov.br/ portal/images/stories/PDFs/livros/livro_caractdasinstituicoesregiao 1. pdf. Accessed in Nov 10, 2021.

13. Camarano AA. Características das instituições de longa permanência para idosos - região Sul. Available from: https://www.ipea.gov.br/portal/ images/stories/PDFs/livros/Livro__CaractdasInstituicoesRegiao_Sul. pdf. Accessed in Nov 10, 2021.

14. Instituto Brasileiro de Geografia e Estatística. Projeções da População. Tabelas - 2018. Available from: https://www.ibge.gov. br/estatisticas/sociais/populacao/9109-projecao-da-populacao. html?edicao=21830\&t=resultados. Accessed in Aug 10, 2021.

15. Instituto Brasileiro de Geografia e Estatística. Pesquisa Nacional de Saúde 2019. Available from: https://www.ibge.gov.br/estatisticas/ sociais/saude/9160-pesquisa-nacional-de-saude.html?=\&t=o-que-e. Accessed in Sep 10, 2021.

16. Brasil. Ministério da Saúde. Secretaria de Atenção à Saúde. Departamento de Ações Programáticas e Estratégicas. Orientações técnicas para a implantação da linha de cuidado para a atenção integral à pessoa idosa no Sistema Único de Saúde. Available from: https://bvsms.saude.gov.br/bvs/publicacoes/linha_cuidado_atencao_ pessoa idosa.pdf. Accessed in Nov 11, 2021.

17. Wachholz PA, Moreira VG, Oliveira D, Watanabe HAW, Villas Boas PJF. Estimates of infection and mortality from COVID-19 in care homes for older people in Brazil. Geriatr Gerontol Aging. 2020;14(4):290-3.

18. Fu L, Sun Z, He L, Liu F, Jing X. Global long-term care research: a scientometric review. Int J Environ Res Public Health. 2019;16(12):2077. https://doi.org/10.3390/ijerph16122077.
19. Wachholz PA, De Oliveira DC, Hinsliff-Smith K, Devi R, Villas Boas PJF, Shepherd V, et al. Mapping research conducted on long-term care facilities for older people in Brazil: a scoping review. Int J Environ Res Public Health. 2021;18(4):1522. https://doi.org/10.3390/ ijerph18041522.

20. Rodriguez-Mañas L, Rodríguez-Artalejo F, Sinclair AJ. The third transition: the clinical evolution oriented to the contemporary older patient. J Am Med Dir Assoc. 2017;18(1):8-9. https://doi.org/10.1016/j. jamda.2016.10.005.

21. Onder G, Carpenter I, Finne-Soveri H, Gindin J, Frijters D, Henrard JC, et al. Assessment of nursing home residents in Europe: the Services and Health for Elderly in Long TERm care (SHELTER) study. BMC Health Serv Res. 2012;12:5. https://doi.org/10.1186/1472-6963-12-5.

22. Born T, Boechat N. A qualidade dos cuidados ao idoso institucionalizado. In: Freitas EV, Py L, Cançado FAX, Gorzoni MLI, eds. Tratado de Geriatria e Gerontologia. Rio de Janeiro: Guanabara Koogan; 2016. p. 1989-97.

23. National Center for Health Statistics. Vital and Health Statistics. Long-term care providers and services users in the United States, 2015-2016. Analytical and epidemiological studies. Available from: https://www.cdc.gov/nchs/data/series/sr_03/sr03_43-508.pdf. Accessed in Nov 11, 2021.

24. Wang Y, Zhang Q, Spatz ES, Gao Y, Eckenrode S, Johnson F, et al. Persistent geographic variations in availability and quality of nursing home care in the United States: 1996 to 2016. BMC Geriatr 2019;19(1):103. https://doi.org/10.1186/s12877-019-1117-z.

25. Dintrans PV. Do long-term care services match population needs? A spatial analysis of nursing homes in Chile. Plos One. 2018;13(6):e0199522. https://doi.org/10.1371/journal.pone.0199522.

26. Albuquerque MV, Viana ALÁ, Lima LD, Ferreira MP, Fusaro ER, Iozzi FL. Desigualdades regionais na saúde: mudanças observadas no Brasil de 2000 a 2016. Ciênc Saúde Coletiva. 2017;22(4):1055-64 https://doi.org/10.1590/1413-81232017224.26862016

27. Giacomin KC, Duarte YAO, Camarano AA, Nunes DP, Fernandes D. Cuidado e limitacões funcionais em atividades cotidianas ELSI-Brasil. Rev Saúde Pública. 2018;52 Suppl 2:9s. https://doi. org/10.11606/S1518-8787.2018052000650.

28. Wachholz PA, Ferri CP, Mateus E, Mata F, Oliveira D. The COVID-19 situation in Brazilian care homes and actions taken to mitigate infection and reduce mortality. LTC Responses to COVID-19. Available from: https://ltccovid.org/2020/06/29/the-covid-19-situation-inbrazilian-care-homes-and-actions-taken-to-mitigate-infectionand-reduce-mortality/. Accessed in Sep 12, 2021.

29. Scheil-Adlung X. Long-term care protection for older persons: a review of coverage deficits in 46 countries. Available from: https://www.lo. org/wcmsp5/groups/public/---ed_protect/---soc_sec/documents/ publication/wcms_407620.pdf. Accessed in Nov 11, 2021.

30. Garner R, Tanuseputro P, Manuel DG, Sanmartin C. Transitions to long-term and residential care among older Canadians. Health Rep. 2018;29(5):13-23. PMID: 29852053. 